\title{
Onion (Allium cepa L.) yield and phosphorus use efficiency as affected by plant extracted humic acid application
}

Intisar ud Din ${ }^{1 *}$, Muhammad Sarwar ${ }^{2}$, Qudrat Ullah Khan ${ }^{1}$, Muhammad Jamil Khan ${ }^{1}$, Fakhar ud Din $^{3}$ and Fasih ud Din ${ }^{4}$

1. Department of Soil and Environmental Sciences, Gomal University, DI Khan-Pakistan

2. Plant nutrition and Soil Fertility, LRRI, NARC, Islamabad-Pakistan

3. Faculty of Pharmacy, Gomal University, DI Khan-Pakistan

4. ICIT, Faculty of Sciences, Gomal University, DI Khan-Pakistan

*Corresponding author's email: intisardin2018@gmail.com

Citation

Intisar ud Din, Muhammad Sarwar, Qudrat Ullah Khan, Muhammad Jamil Khan, Fakhar ud Din and Fasih ud Din. Onion (Allium cepa L.) yield and phosphorus use efficiency as affected by plant extracted humic acid application. Pure and Applied Biology. Vol. 7, Issue 2, pp590-594. http://dx.doi.org/10.19045/bspab.2018.70073

\begin{tabular}{llll}
\hline \hline Received: $12 / 02 / 2018$ & Revised: 23/04/2018 & Accepted: 28/04/2018 & Online First: 05/05/2018 \\
\hline \hline
\end{tabular}

\section{Abstract}

To study the effect of plant derived Humic acid (HA) on the nutrient use efficiency and yield of onion a pot experiment was conducted in a greenhouse of Land Resources Research Institute, National Agricultural Research Centre Islamabad, during year 2013. The experiment was laid out in Complete randomized design with two factor i.e. HA $\left(150 \mathrm{~mL} 5 \mathrm{~kg}^{-1}\right.$ and $\left.300 \mathrm{~mL} 5 \mathrm{~kg}^{-1}\right)$ and Phosphorus (P) levels $\left(60 \mathrm{~kg} \mathrm{ha}^{-1} \mathrm{P}_{2} \mathrm{O}_{5}(75 \%)\right.$ and $80 \mathrm{~kg} \mathrm{ha}^{-1} \mathrm{P}_{2} \mathrm{O}_{5}(100 \%)$. Soil application of

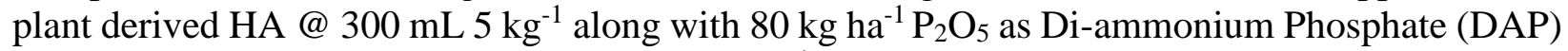
recorded the highest onion yield of $13.47 \mathrm{t} \mathrm{ha}^{-1}$. However it was statistically at par with the treatment receiving 75\% (60 $\left.\mathrm{kg} \mathrm{ha}^{-1}\right) \mathrm{P}$ application along with plant derived HA @ $150{\mathrm{~mL} 5 \mathrm{~kg}^{-}}^{-}$

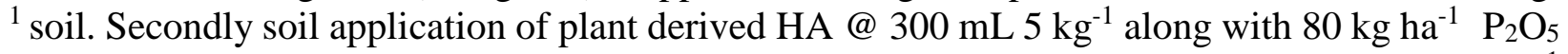

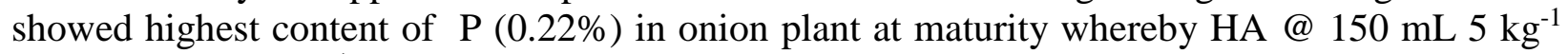
along with $60 \mathrm{~kg} \mathrm{ha}^{-1} \mathrm{P}_{2} \mathrm{O}_{5}(75 \% \mathrm{RDF})$ registered highest content of $\mathrm{N}(4.1 \%)$. It may concluded from the result of the experiments that HA applied @ 300 mL 5 kg-1 integrated with Phosphatic fertilizers gave promising result and may be recommended for enhancing the onion yield and $\mathrm{P}$ and $\mathrm{N}$ concentration of soil.

Keywords: Humic acid; Onion; Phosphorus; Nutrient concentrations; Yield

\section{Introduction}

Onion (Allium cepa L.) belongs to the family Amaryllidaceous which is one of the most important monocotyledonous crops. It is a cross pollinated and cool season vegetable crop. It is widely used and most important vegetable which is grown in temperate and tropical regions of the world. In Pakistan, the total production of onion is 1.7 million tons and grown on an area 129 thousand hectares. The pungency of the onion bulbs is due to the presence of a volatile oil that is allylpropyl disulfide [1]. One of the advantages of onion is that the bulbs can be harvested and sold either 'green' in salads [2], while the mature bulbs are cooked or eaten raw as a vegetable [3]. 
Humic acid is an organically charged biostimulant that significantly affects plant growth and development and increases crop yield. It has been extensively investigated that humic acid improves physical, chemical and biological properties of soils $[4,5]$. The role of humic acid is well known in controlling, soil-borne diseases and improving soil health and nutrient uptake by plants, mineral availability, fruit quality and others [6]. Humic acid based fertilizers increase crop yield, stimulate plant enzymes/hormones and improve soil fertility in an ecologically and environmentally friendly manner $[7,8]$. Several researchers highlighted the positive benefits of humic acid application on higher plants [9]. Humic acids also reduce toxic effects of salts on monocots [10] and dicots [11].

Enhanced nutrient uptake by plants as a result of humic acid application is also well established [12]. Likewise, the increased yield is also observed in many crops due to humic acid application, including potato [13], tomato, onions and other leafy vegetables [14].

Humic substances promote plant growth both directly and indirectly [15]. Indirectly they improves plant growth by improving soil properties such as aggregation, aeration, permeability, water holding capacity, drainage, prevent soil leaching, aids in root formation, hormonal activity, microbial growth, organic matter (OM) mineralization, Suppress diseases, increase solublization and availability of microelements (e.g., Fe, $\mathrm{Zn}$ and $\mathrm{Mn}$ ) and some macro elements (e.g., K, $\mathrm{Ca}$, and $\mathrm{P}$ ) [16]. However, there has been a lot of work cited on soil application of lignite derived humic acid but a little attention has been paid on application of plant extracted humic acid. Thus, this study was planned to assess the effect of plant extracted humic acid on nutrients use efficiency in onion.

\section{Materials and methods}

A pot experiment was carried out in a greenhouse of Land Resources research Institute, National Agricultural research Centre Islamabad to investigate the effect of plant extracted humic acid on nutrients use efficiency in onion. All pots were filled with five kilogram of clay loam soil after sieving. The basic characteristics are mentioned in (Table 1). Two onion plants were transferred to each pot and then the plant extracted humic acid and fertilizer were applied to each pot. There were 6 treatments $\left(\mathrm{T}_{1}=\mathrm{HA}_{0}+75 \% \mathrm{~F}\right.$, $\mathrm{T}_{2}=\mathrm{HA}_{0}+100 \% \mathrm{~F}, \mathrm{~T}_{3}=\mathrm{HA}_{150 \mathrm{ml}}+75 \% \mathrm{~F}$, $\mathrm{T}_{4}=\mathrm{HA}_{150 \mathrm{ml}}+100 \% \mathrm{~F}, \mathrm{~T}_{5}=\mathrm{HA}_{300 \mathrm{ml}}+75 \%$ $\mathrm{F}$ and $\mathrm{T}_{6}=\mathrm{HA}_{300 \mathrm{ml}}+100 \% \mathrm{~F}$ ) replicated 3 times. The experiment was laid in Complete Randomized design with two factors. Factor 1 is the fertilizer levels (75\% and $100 \%)$ of the recommended doses of $\mathrm{N}$ and $\mathrm{P}$ fertilizers (Urea and DAP) and factor 2 was the humic acid (HA @ $150 \mathrm{ml} 5 \mathrm{~kg}^{-1}$ and $300 \mathrm{ml} 5 \mathrm{~kg}^{-}$ $\left.{ }^{1}\right)$. The composite sample was collected and analysed for various physic - chemical characteristics of soil [17]. Nitrate nitrogen, extractable Phosphorus and extractable potassium were carried out by AB - DTPA method [18]. The plant tissues analysis was carried out by wet digestion and phosphorus content by using spectrophotometer at 410 $\mathrm{nm}$ [17]. Potassium was determined by Flame photometer.

\section{Results and discussion Onion yield ( $\mathbf{t ~ h a}^{-1}$ )}

Data about interactive effect of humic acid along with $\mathrm{P}$ on onion yield ( $\mathrm{tha}^{-1}$ ) is given in (Table 2). Soil application of plant derived HA @ 300 mL $5 \mathrm{~kg}^{-1}$ along with $80 \mathrm{~kg} \mathrm{ha}^{-1}$ $\mathrm{P}_{2} \mathrm{O}_{5}$ as DAP $(100 \% \mathrm{P})$ recorded the highest onion yield of $13.47 \mathrm{t} \mathrm{ha}^{-1}$. However it was statistically at par with the treatment receiving $75 \%\left(60 \mathrm{~kg} \mathrm{ha}^{-1}\right) \mathrm{P}$ application along with soil application of plant derived HA @ $150 \mathrm{~mL} 5 \mathrm{~kg}^{-1}$. Similar findings have been reported by different researchers [19]. 
Table1. The basic soil characteristic of the experimental soil

\begin{tabular}{|c|c|c|}
\hline Soil characteristics & Unit & Values \\
\hline $\mathrm{pH}$ & - & 7.21 \\
\hline $\mathrm{EC}(1: 1)$ & $\left(\mathrm{dS} \mathrm{m}^{-1}\right)$ & 0.2 \\
\hline $\mathrm{NO}_{3}-\mathrm{N}$ & $\left(\mathrm{mg} \mathrm{kg}^{-1}\right)$ & 2.8 \\
\hline Extractable $\mathrm{K}$ & $\left(\mathrm{mg} \mathrm{kg}^{-1}\right)$ & 126 \\
\hline Extractable P & $\left(\mathrm{mg} \mathrm{kg}^{-1}\right)$ & 2.15 \\
\hline CEC & $\mathrm{Cmol} \mathrm{kg}^{-1}$ & 27.5 \\
\hline Textural Class & & Clay loam \\
\hline
\end{tabular}

Table 2. Effect of Plant Extracted Humic Acid and $\mathbf{P}$ fertilizer application on onion yield (t ha $^{-1}$ )

\begin{tabular}{|c|c|c|c|c|}
\hline \multirow{2}{*}{ Phosphorus } & \multicolumn{4}{|c|}{ Humic acid (HA) } \\
\cline { 2 - 5 } & HA (0) & HA 150 mL 5 kg-1 & HA 300 mL 5 kg-1 & Means \\
\hline \multicolumn{4}{|c|}{ Yield $\left(\mathrm{t} \mathrm{ha}^{-1}\right)$} \\
\hline $60 \mathrm{~kg} \mathrm{ha}^{-1} \mathrm{P}_{2} \mathrm{O}_{5}(75 \%)$ & $9.6 \mathrm{c}$ & $13.47 \mathrm{a}$ & $10.4 \mathrm{bc}$ & $11.69 \mathrm{~b}$ \\
\hline $80 \mathrm{~kg} \mathrm{ha}^{-1} \mathrm{P}_{2} \mathrm{O}_{5}(100 \%)$ & $12.93 \mathrm{ab}$ & $13.47 \mathrm{a}$ & $13.47 \mathrm{a}$ & $13.29 \mathrm{a}$ \\
\hline Means & $11.265 \mathrm{~b}$ & $13.47 \mathrm{a}$ & $11.935 \mathrm{a}$ & \\
\hline
\end{tabular}

Means followed by similar letter(s) did not differ significantly at 0.05 level of significance

\section{Phosphorus content in onion (\%)}

Phosphorus content in whole plant onion including bulb at maturity was analyzed (Table 3). The results showed that soil application of plant extracted humic acid @300 mL 5 kg along with $80 \mathrm{~kg} \mathrm{ha}^{-1} \mathrm{P}_{2} \mathrm{O}_{5}$ as DAP $(100 \% \mathrm{P})$ showed significant concentration of $\mathrm{P}$ $(0.22 \%)$ followed by $\mathrm{P}$ concentration
$(0.21 \%)$ in the treatment receiving plant extracted humic acid @ $150 \mathrm{~mL} 5 \mathrm{~kg}^{-1}$ along with $60 \mathrm{~kg} \mathrm{ha}^{-1} \mathrm{P}_{2} \mathrm{O}_{5}$. The increase in $\mathrm{P}$ concentration might be due to the prevention of $\mathrm{P}$ fixation in the soil and the formation of homophospho complexes, which are easily assimilable by the plants [20].

Table 3. Effect of Plant Extracted Humic Acid application on Phosphorus concentration (\%) in onion

\begin{tabular}{|l|c|c|c|c|}
\hline \multirow{2}{*}{ Phosphorus } & \multicolumn{4}{|c|}{ Humic acid (HA) } \\
\cline { 2 - 5 } & HA (0) & HA 150 mL 5 kg-1 & HA 300 mL 5 kg & Means \\
\hline \multicolumn{4}{|c|}{ P Concentrations \% } \\
\hline $60 \mathrm{~kg} \mathrm{ha}^{-1} \mathrm{P}_{2} \mathrm{O}_{5}(75 \%)$ & $0.163 \mathrm{c}$ & $0.21 \mathrm{~b}$ & $0.163 \mathrm{c}$ & $0.178 \mathrm{~b}$ \\
\hline $80 \mathrm{~kg} \mathrm{ha}^{-1} \mathrm{P}_{2} \mathrm{O}_{5}(100 \%)$ & $0.213 \mathrm{~b}$ & $0.21 \mathrm{~b}$ & $0.223 \mathrm{a}$ & $0.215 \mathrm{a}$ \\
\hline Means & $0.188 \mathrm{c}$ & $0.21 \mathrm{~b}$ & $0.386 \mathrm{a}$ & \\
\hline
\end{tabular}

Means followed by similar letter(s) did not differ significantly at 0.05 level of significance

\section{Nitrogen content in onion $(\%)$}

Results reveal that onion N (\%) content were increased with the interaction of plant derived $\mathrm{HA}$ and $\mathrm{P}$ fertilizer (Table 4). The results showed that soil application of plant extracted humic acid@150 mL 5 kg-1 along with $60 \mathrm{~kg}$ ha $^{-1} \mathrm{P}_{2} \mathrm{O}_{5}$ as DAP $(75 \% \mathrm{P})$ showed significant concentration of $\mathrm{N}(4.1 \%)$ followed by $\mathrm{N}$ concentration $(3.88 \%)$ in the treatment receiving plant extracted humic acid @ 300 $\mathrm{mL} 5 \mathrm{~kg}^{-1}$ along with $80 \mathrm{~kg} \mathrm{ha}^{-1} \mathrm{P}_{2} \mathrm{O}_{5}$ The increased $\mathrm{N}$ concentration was supposed to be retarded nitrification process with humic 
acid application enabling the slow availability of applied $\mathrm{N}$ [21].

Table 4. Effect of Plant Extracted Humic Acid application on N Concentration (\%) in Onion

\begin{tabular}{|l|c|c|c|c|}
\hline \multirow{2}{*}{ Phosphorus } & \multicolumn{4}{|c|}{ Humic Acid (HA) } \\
\cline { 2 - 5 } & HA (0) & HA 150 mL 5 kg & HA 300 mL 5 kg & Means \\
\hline \multicolumn{4}{|c|}{ N Concentration (\%) } \\
\hline $60 \mathrm{~kg} \mathrm{ha}^{-1} \mathrm{P}_{2} \mathrm{O}_{5}(75 \%)$ & $1.71 \mathrm{e}$ & $4.1 \mathrm{a}$ & $3.55 \mathrm{c}$ & $3.12 \mathrm{a}$ \\
\hline $80 \mathrm{~kg} \mathrm{ha}^{-1} \mathrm{P}_{2} \mathrm{O}_{5}(100 \%)$ & $2.7 \mathrm{~d}$ & $3.69 \mathrm{bc}$ & $3.88 \mathrm{ab}$ & $3.42 \mathrm{a}$ \\
\hline Means & $2.205 \mathrm{~b}$ & $3.895 \mathrm{a}$ & $3.715 \mathrm{a}$ & \\
\hline
\end{tabular}

Means followed by similar letter(s) did not differ significantly at 0.05 level of significance

Potassium content onion (\%)

Potassium content in whole plant onion including bulb at maturity was analyzed (Table 5). Soil application of plant extracted humic acid did not affect significantly concentration of $\mathrm{K}$ in whole shoot onion. It may be due to the complex bonding of nutrients with humic acid which suppress nutrients availability. These result were analogous to the findings made by other researchers [22]. However, the results show increasing trend of $\mathrm{K}$ content in onion with the application of plant extracted humic acid.

Table 5. Effect of Plant Extracted Humic Acid application on K concentration (\%) in Onion

\begin{tabular}{|l|c|c|c|c|}
\hline \multirow{2}{*}{ Phosphorus } & \multicolumn{4}{|c|}{ Humic Acid (HA) } \\
\cline { 2 - 5 } & HA (0) & HA150 mL 5 kg & HA300 mL 5 kg & Means \\
\hline \multicolumn{4}{|c|}{ K Concentration (\%) } \\
\hline $60 \mathrm{~kg} \mathrm{ha}^{-1} \mathrm{P}_{2} \mathrm{O}_{5}(75 \%)$ & 1.63 & 1.93 & $2.48 \mathrm{NS}$ & $2.01 \mathrm{NS}$ \\
\hline $80 \mathrm{~kg} \mathrm{ha}^{-1} \mathrm{P}_{2} \mathrm{O}_{5}(100 \%)$ & 1.66 & 2.15 & 2.33 & 2.04 \\
\hline Means & 1.64 & 2.04 & $2.40 \mathrm{NS}$ & \\
\hline
\end{tabular}

NS Non-Significant

\section{Conclusion}

Soil application of plant derived HA @ 300 $\mathrm{mL} 5 \mathrm{~kg}^{-1}$ along with $80 \mathrm{~kg} \mathrm{ha}^{-1} \mathrm{P}_{2} \mathrm{O}_{5}$ as DAP $(100 \% \mathrm{P})$ recorded the highest onion yield of $13.47 \mathrm{t} \mathrm{ha}^{-1}$. However it was statistically at par with the treatment receiving $75 \%(60 \mathrm{~kg}$ ha $^{-1}$ ) $\mathrm{P}$ application along with plant derived HA @ $150 \mathrm{~mL} 5 \mathrm{~kg}^{-1}$. So application of inorganic fertilizers along with the humic acid may be recommended for increasing the yield of onion and also the $\mathrm{P}$ and $\mathrm{N}$ concentrations in onion crop.

\section{Authors' contributions}

Conceived and designed the experiments: IU Din \& M Sarwar, Performed the experiments: D Intisar, Analyzed the data: QU Khan \& MJ Khan, Contributed materials/ analysis/ tools:
D Fakhar, D Fasih \& M Sarwar, Wrote the paper: D Intisar \& QU Khan.

\section{References}

1. Baloch AF (1994). Vegetable crops. Horticulture. National Book Foundation. Islamabad. pp. 489-537.

2. Lannoy G De (2001). Vegetable Crops in Tropical Africa 395-511. In: Raemaeks R. H. (Editor). Crop Production in Tropical Africa. $1540 \mathrm{pp}$. Directorate General for International Cooperation (DGIC) Belgium.

3. Straub RW \& Emmett B (1992). Pests of Monocotyledon. Crops. In: Mc Kinlay, R.G. (Editor). Vegetable Crop Pests. Macmillan Press. UK. pp. 213-262.

4. Nardi S, Pizzeghello D \& Pandalai SG (2004). Rhizosphere: A communication between plant and soil. Recent Res Dev Crop Sci 1(2): 349-360. 
5. Mikkelsen RL (2005). Humic materials for agriculture, Davis, California, USA. Better Crops Plant Food 89(3): 6-7.

6. Mauromicale G, Angela MGL \& Monaco AL (2011). The effect of organic supplementation of solarized soil on the quality of tomato. Scientia Horticulture 129 (2): 189-196.

7. Mart I (2007). Fertilizers, organic fertilizers, plant and agricultural fertilizers. Agro and Food Business Newsletter pp. i-iv.

8. Sarir MS, Sharif M, Ahmed Z \& Akhlaq M (2005). Influence of different levels of humic acid application by various methods on the yield and yield components of maize. Sarhad J Agric 21(1): 75-81.

9. Susilawati $\mathrm{K}$, Ahmed $\mathrm{OH}$, Muhammad AMN \& Hanif MY (2009). Effect of organic based $\mathrm{N}$ fertilizer on dry matter (Zea mays L.), ammonium and nitrate recovery in an acid soil of Sarawak, Malaysia. Amer J Appl Sci 6(7): 1282-1287.

10. Masciandaro G, Ceccanti B, Ronchi, V, Benedicto S \& Howard L (2002). Humic substances to reduce salts effect on germination and growth of plants. Commun. Soil Sci Plant Anal 33(3-4): 365-378.

11. Ferrara G, Loffredo E, Senesi N, Ghabbour, EA \& Davies G (2001). Anti-mutagenic and antitoxic actions of humic substances on seedlings of monocotyledons and dicotyledon plants. In: Humic substances: Structures, Models and Functions: Proceedings of the 5th Humic Substances Seminar held at Northwestern University, Boston, Massachusetts, USA, 21-23, Mar. pp. 361-371.

12. Sharif MA, Ahmad MS \& Khattak RA (2004). Effect of organic and inorganic fertilizers on the yield and yield components of maize. Pak J Agric Agric Engin Vet Sci 20(1): 11-16.

13. Vetayasuporn $\mathrm{S}$ (2006). Effects of biological and chemical fertilizers on growth and yield of glutinous corn production. J Agronomy 5(1): $1-4$.
14. Erik BGF, Shock CC \& Saunders LD (2000). Evaluation of humic acid and other non-conventional fertilizer additives for mustard production. Malheur Experimental Station, Oregon State University, Ontario pp. 1-15

15. Nardi S, Pizzeghello A \& Vianello A (2002). Physiological effects of humic substances on higher plants. Soil Bio Biochem. 34: 15271536

16. Sharif M, Khattak RA \& Sarir MS (2002). Effect of different levels of lignitic coal derived humic acid on growth of maize plants. Commun Soil Sci Plant Anal 33:3567-3580.

17. Ryan J, Estefan G \& Rashid A (2001). Soil and Plant Analysis Laboratory Manual. International Center for Agricultural Research in the Dry Areas (ICARDA), Aleppo, Syria $172 \mathrm{pp}$.

18. Soltanpour PN \& Workman S (1979). Modification of the $\mathrm{NH}_{4} \mathrm{CO}_{3}$ DTPA soil to omit carbon black. Commun Soil Sci Plant Anal 10(11): 411 - 20.

19. Sharma RP, Datt N \& Chander G (2009). Effect of Vermicompost, FYM, and chemical fertilizers on yield and nutrient uptake and soil fertility in okra-onion sequence in wet temperate zone of Himachal Pradesh. J Indian Soc Soil Sci 57(3): 357361.

20. Raina JN \& Goswami KP (1988). Effect of fulvic acid and fulvates on the growth and / nutrient uptake by maize plant. J Indian Soc Soil Sci 36: 264-268.

21. Guminski S. 1968. Present-day views on physiological effects induced in plant organisms by humic compounds. Soviet Soil Sci 9: 1250-1256.

22. Timothy KH \& Bottoms TG (2010). Humic Substances Generally Ineffective in Improving Vegetable Crop Nutrient Uptake or Productivity. Hort Sci 30(6): 906-910. 